\title{
ANALYSIS OF SEASONALITY IMPACT ON THE BUSINESS PERFORMANCE OF GLOBAL CHAIN HOTELS
}

\author{
Sanela Vrkljan \\ Petra Barišić \\ Katarina Vrenc
}

https://doi.org/10.20867/tosee.05.11

\begin{abstract}
Starting with the notion that seasonality is one of the greatest challenges for the most hotels and tourist destinations, and without an exception for the hotels in European Mediterranean destination, this paper aims to gain knowledge of the coherence between business performance of global chain hotels and degree of seasonality, and if business or leisure hotels are more successful from the aspect of seasonality degree. Business performance is approximated by the following indicators: accommodation occupancy, average daily room rate (ADR) and revenue per available room (RevPAR). Data was collected via questionnaire from 196 global chain hotels from four Mediterranean tourist destinations (Croatia, Italy, Spain and Turkey). The data were analyzed using descriptive, inferential and multivariate statistics. The study concludes that there is a difference in business performance of the global chain hotels depending on the degree of seasonality. As the seasonality degree is lower, the hotels' business performance is higher. It is found that targeting the leisure or business hotel type cannot make the influence on the more favorable degree of seasonality. The paper contributes to theoretical and practical understanding of seasonality impact on the business performance of global chain hotels.

Keywords seasonality, business performance, business hotel, leisure hotel, global chain hotels
\end{abstract}

\section{INTRODUCTION}

Seasonality is one of the most influential factors to the hotel business performance. It is considered to be a factor of competitiveness of global chain hotels (hereinafter: GCHs) and hotels in general. The basic causes of the seasonality of tourism demand are climate factors which define the main tourist resource and limit its all-year-round use, as well as social factors which are most often reflected in tourists' annual vacation habits usage during summer or winter months, and school holidays (Butler and Mao, 1997; Frechtling, 2001; Baum and Hagen, 1999; Riera Font, Ripoll Penalva and Juaneda Sampol, 2011, 846). To sum up, it is a natural and institutional seasonality of tourism (BarOn, 1975; Butler, 1994; Hartmann, 1986).

Most tourist destinations and this is almost the rule with leisure destinations, are under the high influence of seasonality. The larger part of tourism movements is limited to a few summer or winter months when it takes massive proportions. Accordingly, one of the basic tourism business specificities of the most receptive destinations is pronounced seasonality, which is not the case with a large number of other industries. The result is 
ToSEE - Tourism in Southern and Eastern Europe, Vol. 5, pp. 757-772, 2019

S. Vrkljan, P. Barišić, K. Vrenc: ANALYSIS OF SEASONALITY IMPACT ON THE BUSINESS ...

an uneven distribution of tourist traffic that generates numerous negative (Škorić, 2010, 5), but also some positive effects (Grant, Human and Le Pelley, 1997, 9).

BarOn (1975) carried out the first comprehensive survey of seasonality in tourism. Since then, a large number of articles, reports and case studies have been published dealing with various aspects of seasonality in tourism (Koenig-Lewis and Bischoff, 2005, 201). For example, Kožić (2013) investigated the level of tourism seasonality in selected European countries (Cyprus, Montenegro, France, Greece, Italy, Malta, Portugal and Spain). The analysis was based on the total number of tourist nights in hotels and similar accommodation facilities, and in other commercial accommodation facilities. The research has shown that each of the sampling destinations faces the seasonality of tourist nights. In addition, it was found that the source of the high degree of tourism seasonality in Croatia lies in hotel accommodation concentrated on the coast with a strong "sun and sea" image.

Studying secondary data sources in search of scientific knowledge considering seasonality impact on hotel business performance, as well as if it's possible to influence on more favorable seasonality degree by focusing on a single hotel type, it was determined that this area hasn't been sufficiently researched. Researches made to date that consider seasonality topics in hotel industry were dominantly focused on challenges in revenue management domain due to business seasonality (e.g. Pereira, 2016; Weatherford, 2016), or on seasonality business research in hotel management and/or seasonality degree movement over time (e.g. De Santis, Ferrante and Vaccina, 2011; Duro, 2016). One of the few who explored the connection of certain hotel characteristics and seasonality of business is Espinet et al. (2012), who focused on seasonality of rates, as well as Salo et al. (2012), who is comparing seasonality degree between hotels and private accommodation in Spain. According to the authors knowledge, the only research so far that was trying to relate hotels' aims towards business segment and hotel business seasonality is of authors Sainaghi and Canali (2011) whose analysis is focused on hotels located in Milano. The research of Lam and Lei (2010) is based on the related topic focusing on hotels in gambling destination, i.e. in Macao and they've reached the conclusion that the hotel occupancy level is not affected by seasonality. In other words, focusing towards specific segment guests, in this case very precise, can have a positive effect on business seasonality mitigation.

Considering insufficient researches of the seasonality impact on hotels' business performance, both business and leisure hotels, the same is set as the goal of this research. The main objective of this paper is to explore the impact of seasonality on business performance of business and leisure global chain hotels. Based on preceding examination of previous research in this field, the following hypotheses will be tested using data collected by primary research through the questionnaire:

H1: Business performance of the global chain hotels approximated by the room occupancy, average daily room rate (ADR) and revenue per available room (RevPAR) is higher in hotels with a lower degree of seasonality.

H2: The degree of business seasonality is lower for business global chain hotels, than the degree of business seasonality for leisure global chain hotels. 
ToSEE - Tourism in Southern and Eastern Europe, Vol. 5, pp. 757-772, 2019

S. Vrkljan, P. Barišić, K. Vrenc: ANALYSIS OF SEASONALITY IMPACT ON THE BUSINESS ...

The focus of this research will be on a larger number of countries (Croatia, Italy, Spain and Turkey) with comparable tourism products.

\section{SEASONALITY OF THE BUSINESS PERFORMANCE OF HOTELS}

Space for pro-active performance towards the reduction of negative seasonality effects on hotel's business is limited, considering the fact that hotel service, in general, is rigid and inflexible. Hotel offer will react slowly to market changes or will no react at all, and the structural changes usually require significant investments, as well as a certain period needed for implementation of development projects, where extra investments are increasing service prices making them less competitive in tourism market (Cerović, Pavia and Galičić, 2005, 35).

One of the negative effects of seasonality in tourism is the challenge of employing additional seasonal human resources, apart from that several other negative effects can be connected to the seasonality in tourism. Čavlek et al. $(2011,320)$ as negative effects states: (i) inconsistency in achieving the effects over the year (of seasonal character), (ii) increase in value of the national currency for the duration of the tourist season (seasonal appreciation), (iii) increase in the price of products and services in the tourist receptive destinations during the season (seasonal inflation), (iv) Trap of excessive dependence of economy on tourism, (v) low rate of return on capital investments, (vi) cash outflow from the destinations for payment of foreign employees, etc. There are other negative sides of seasonal business such as unused accommodation facilities, infrastructure and other capacities of the destinations out of season, traffic jams in the season etc. One of few advantages include the result of reduced tourist activity offseason is allowing the restoration of natural resources, and the construction and infrastructure works can be carried out without noise and visual disturbance to the tourist experience.

Seasonality is one of the main characteristics of tourist demand. The specificity of demand is reflected in the seasonal tendency of demand for new tourism products that are not related to the weather conditions and holidays leading to demand throughout the year and a larger number of shorter trips (Vrkljan, 2016, 42). This trend of shorter trips has been strongly increasing since the great economic world crisis of 2008 and a significant contribution to it are more affordable air transport and technological advances in transport.

Another important trend in tourist travel is demographic shifts. It is anticipated that the number of citizens older than 60 years in the world rises from 900 million in 2010 to almost 1.4 billion by 2030 . Older travelers require higher standards of quality and refinement, having a little higher budget and are not seasonal guests (WEF, 2015, 25). Typical "sun, sea and sand" leisure holiday is no longer answer to the demands of modern tourists who are looking for an active vacation and expect participation, activities, and learning. Active leisure time has a functional objective of raising the level of quality of life (Bartoluci and Škorić, 2009, 74). Younger tourists, especially millennium guests, are not very interested in traditional leisure packages but are motivated to increase their knowledge about the world and the experience of living in other countries. Younger tourists rely on new technologies and on-line services in order to create their own tourist 
ToSEE - Tourism in Southern and Eastern Europe, Vol. 5, pp. 757-772, 2019

S. Vrkljan, P. Barišić, K. Vrenc: ANALYSIS OF SEASONALITY IMPACT ON THE BUSINESS ...

experience, always using the sharing economy (WEF, 2015, 26). It can be said that they are interested in sharing and involvement and that their activities related to the journey are taking place using digital technology.

Walker (2008) uses the criteria of seasonality to classify hotels on a year-round and seasonal. A similar classification of the hotels is used by Ružić $(1997,33 / 34)$, which, with regard to business continuity, divides hotels into (i) permanently open hotels, (ii) hotels open year-round and (iii) seasonal hotels. Since hotels cannot influence the climate factors that determine the seasonality and basic offer, mitigating the effects of the seasonality hotels can achieve only through a partial adjustment of their offers. It is possible to identify two foundations that need to be set up to ensure the year-round of business, such as the growth of high-quality hotel accommodation in the destination and enriching of the non-accommodation offer in the destinations. Since the tourism and hotel offer are the answer to tourist demand, it is necessary to create a hotel product that will be in compliance with the new requirements of tourism demand and specific market niches as well as smart specialization of business can offset the seasonality of the business.

There is no single world wide's or European formal classification of hotels that would prescribe standard criteria for the classification. Standards in the hotels expressed by the number of stars, as the most common mode of categorization, can vary from country to country. Each country according to the state of their hotel network, the standard of living and the importance of the hotel for domestic and foreign tourism determines the norms (Galičić, Ivanović and Lupić, 2005, 14). Quality standards in hotel chains are not specified by star rating, but by brands that are classified by the market category of quality, usually on: budget, midscale, upscale and luxury category. On the same basis, the completeness of the service provided, and the prices and quality levels, in similar category hotels are divided by Ruzic (1997, 33/34), Walker (2008), Xiao, O'Neill and Mattila (2012, 128), Angelo and Vladimir (2004, 150) and other authors. In all of the hotels of the same chain is guaranteed the same standard of quality, regardless of the country where the hotel is located (Avelini Holjevac, 1998, 72). Hotel chains have done breakthrough in categorization or market orientation by branding. When set standardization as a guarantee of a certain level of quality, every hotel builds its recognition on the market through the diversification of offer and determinants of quality of service.

The specifics of certain types of hotels arising from the global market orientation and are determined by the motive of arrival into a certain hotel (Galičić, Ivanović and Lupić, $2005,11)$. The hotel must define and understand the market segment that will serve and look for those segments that may enable it maximum profitability (Carmona Olmos, 2012,37). Mass tourism is the past in many countries, and the guests are more demanding and expect the fulfilment of their specific requirements and desires. Since it is impossible to meet the expectations of all guests, hotels have segmented the market and adapt their offers to certain target groups so they can offer superior products and services from the competition to their target groups. Maximizing revenue requires segmentation of the users in the narrowest possible categories in order to understand their characteristics, patterns of purchase, the perception of the product and the ability to pay a certain price (Cross, 1997, 9). 
ToSEE - Tourism in Southern and Eastern Europe, Vol. 5, pp. 757-772, 2019

S. Vrkljan, P. Barišić, K. Vrenc: ANALYSIS OF SEASONALITY IMPACT ON THE BUSINESS ...

In the hotel industry, there are numerous approaches of hotel guests' segmentation and hotel segmentation as per their primary focus to a particular segment. Angelo and Vladimir $(2004,147)$ segment guests into following categories: (i) corporate guests individuals, (ii) corporate groups, (iii) conference groups, (iv) leisure travelers, (v) guests on a long vacation, (vi) guests orientated to airports, (vii) government and military travelers and (viii) guests that are "running" within the region. Ružić (1997, 33/34) classifies hotels having in mind global market focus on (i) tourist hotels (a stationary stay of guests), (ii) business hotels (seminar, congress), (iii) sports hotels (with sports facilities) and (iv) city hotels (varied market focus). With regard to the motive for arrival, Walker (2008) classifies hotels as (i) business, (ii) congress, (iii) leisure, (iv) family, (v) wellness and (vi) casino hotels. A similar classification is used by Galičić, Ivanović, and Lupić $(2005,19)$, which in addition to the above types of hotels further identify garni hotels, suite hotels, airport hotels, timeshare hotels and condominium (co-ownership) hotels.

Most often encountered evidence of guests in hotels can be divided into two primary segments: business and leisure guests. Therefore, we could consider business and leisure hotels as two main types of the hotels. Business guests are those who are checking into a hotel or coming to a destination for a conference, a business meeting or any other business reason. Mostly they are recorded as conference and business guests. All other guests not traveling for business motives, but for other motives such as leisure or wellness, casino etc., are recorded as leisure guests. More than a half of international tourist visits $(55 \%)$ in 2017 were due to the leisure, recreation or holiday motives, $13 \%$ of tourists have traveled due to business and professional purposes, and the remaining $27 \%$ traveled for different reasons like visiting friends and family, health and religious reasons etc. (UNWTO Tourism Highlights, 2018, 3).

Congress tourism is often mentioned as an ideal form of tourism for extension of tourist season or a year-round business as it usually takes place out of high tourist season. If a hotel is a leisure type, to have a conference offer will demand adjustment of the hotel through the construction or release of the halls for meetings and conventions. Conference guests spend three times more money than is average of mass tourism consumption (Vidić, 2002, 28). In general, it is considered that business tourists are mostly highly educated people who have higher personal income and higher credit standing (Gračan and Rudančić Lugarić, 2011, 580). Therefore, Gračan and Rudančić Lugarić (2011, 582) conclude that business tourism has a multiplicative effect on economic and social components of the destination through development towards the high-quality destination. Increasing consumption by convention guests results in the faster return of the invested capital as opposed to those hotels or destinations committed to mass tourism so the adjustment of offer and hotel services for/and this market segment are often the choice for both city and leisure hotels. Larger hotels and GCHs along with loyalty programs for individual guests also develop business (B2B) programs for travel agencies (organizers of congresses and other events, a group of guests, etc.). Business loyalty programs serve as a platform for communication and education about the hotel products and services with the aim of gaining the loyalty of travel agencies so that they could become the ambassadors of the hotel brand. 
ToSEE - Tourism in Southern and Eastern Europe, Vol. 5, pp. 757-772, 2019

S. Vrkljan, P. Barišić, K. Vrenc: ANALYSIS OF SEASONALITY IMPACT ON THE BUSINESS ...

Hotels with their services can be directed to the segment of leisure tourism or business tourism segment. If they do business in a location that is due to climate conditions influenced by seasonality, exclusively focus on one of these two segments will not offset the negative impact of seasonality nor provide optimal business performance.

As the most important financial indicators of hotel's business performance most often are used revenue per available room (RevPAR), average daily rate (ADR) and occupation, and net operating income often used as an indicator in investment analysis as the indicator of future returns (Xiao, O'Neill and Mattila, 2012, 127). Considering the occupancy analysis the seasonality, the convention facilities or other facilities and services in the hotel and its surroundings that affect the average occupation of the accommodation facilities should be taken into account. Average daily rate depend on hotel's pricing policy, and also, if it is used independently it can lead to wrong conclusions on hotel's business performance. Prices of hotel's products and services are highly variable according to the product type, competition's prices and the period in which the guests are using them (during the season, pre-season or post-season, for the holidays etc.). Dulčić and Petrić $(2001,298)$ state that the prices for tourist services during the season are considerably above the marginal costs. This is due to the fact that there is a maximum demand during the season which, at some destinations exceeds offer capacities, especially for hospitality services like accommodation and food and beverages services. Maximizing the prices of the tourist services during the season is possible to a certain level considering price-competitiveness of other destinations. That is not defined only by the offer and demand, but also with the input prices which bring high costs (material costs, amortization, insured wages etc.) (Bartoluci, 2013, 337). Sainaghi $(2011,25)$ has been researching the impact of certain factors on prices in independent hotels in Milano area and among other results concluded that the existence of conference capacities is not considerably related to the rates. However, financial management in every hotel is directly related to managing the rates and therefore rates can be considered as one of the key indicators of the business performance and hotel's competitiveness factors. Therefore, chain hotels base their pricing policy on the best available rate (BAR) which is defined accordingly to a series of previously indicated factors, especially based on the earlier experience of the occupancy, seasonality and competition's rates. Except for the delivery on the promise of providing best available rate, comparing hotel's rates with other hotels serves as a rates and brand erosion control mechanism (Gazzoli, Kim and Palakurthi, 2008, 376). Considering positive and negative sides of occupancy and average daily rates as the indicators of business performance, it is recommended to use, as a more reliable indicator of hotel's business performance, the revenue per available room (RevPAR).

\section{METHODOLOGY}

Quantitative research was conducted on a basic sample of 757 GCHs of selected hotel chains from four countries of the European Mediterranean region as the strongest receptive tourist destination in the world: Croatia (26 hotels), Italy (314 hotels), Spain (307 hotels) and Turkey (110 hotels) from September till December, 2015. Globality of hotel chains were defined as being present on at least two continents and in 25 countries or more. Additional criteria for selecting global hotel chain was its presence on Croatian 
ToSEE - Tourism in Southern and Eastern Europe, Vol. 5, pp. 757-772, 2019

S. Vrkljan, P. Barišić, K. Vrenc: ANALYSIS OF SEASONALITY IMPACT ON THE BUSINESS ...

market. A hotel database of all chosen hotel chain brands were created for chosen countries. Chosen hotel chains were Hilton Hotels \& Resorts, Carlson Rezidor, Kempinski, Meliá Hotels International, Marriott International (including Starwood Hotels \& Resorts Worldwide), Best Western International and Leading Hotels of the World. Best Western and Leading Hotels of the World are hotel consortiums that do not manage hotels, but because of selection of services offered to their members and their global recognition and power, they often identify with hotel chains. In recent years, franchise agreements and management agreements of these companies are more frequently recorded. That is why it is considered reasonable to include them in the research. An additional reason for their inclusion is an extremely small number of GCHs in Croatia. A total of 196 replies were received which made the average return rate of $38,17 \%$. Special attention was given so that all global hotel chains from the basic sample are represented by all brands with which they operate in countries where the research was conducted.

Survey method was used for quantitative research. Three variables were selected to measure business performance - occupancy, average daily rate (hereinafter: ADR) and RevPAR, as they are the most often used indicators of hotel business performance in theory and practice. For testing the proposed relationship, RevPAR was used as the most reliable indicator.

The following conceptual model (Figure 1) can represent relationships among the variables that are examined by the set hypotheses.

\section{Figure 1: Seasonality influence model on global hotel chain performance with corresponding hypothesis}

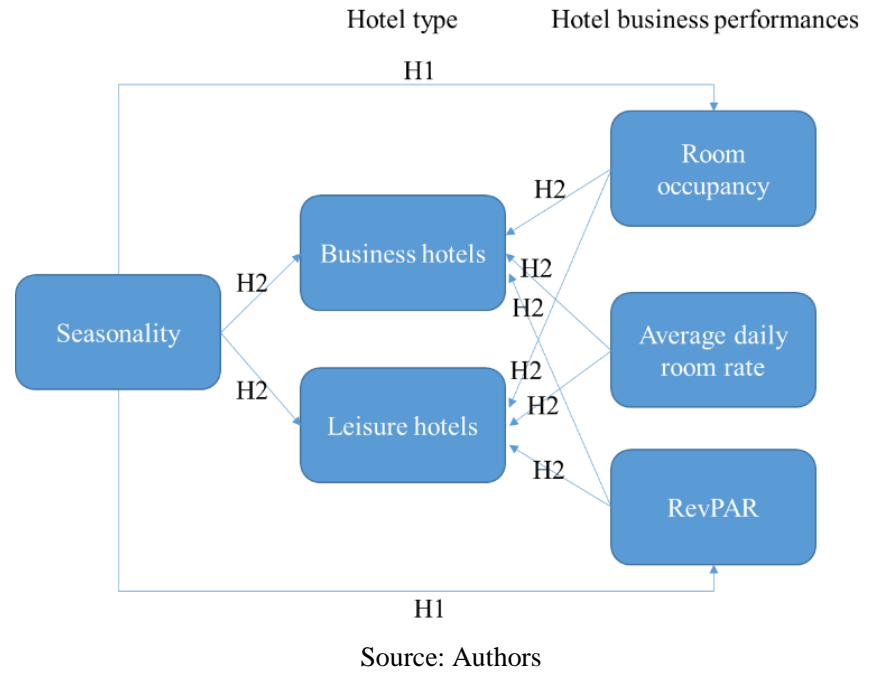


ToSEE - Tourism in Southern and Eastern Europe, Vol. 5, pp. 757-772, 2019

S. Vrkljan, P. Barišić, K. Vrenc: ANALYSIS OF SEASONALITY IMPACT ON THE BUSINESS ...

The degree of seasonality is based on the answers given to the question in the questionnaire about the number of high season days in the business of a particular GCH. It is considered, if the degree of seasonality is lower, the high season is longer. In order to define the degree of seasonality and to determine the limits of each degree, a TwoStep Cluster Analysis has been applied. The first step of the TwoStep Cluster Analysis is comprised of the pre-clustering procedure. In this step based on answers given about the number of high season days, clusters representing degrees of seasonality are formed, while in the second step the hierarchical cluster analysis of the formed clusters is implemented in order to determine for each hotel to which degree of seasonality it belongs. The variable that has entered in the analysis is the number of days of high season in a hotel's operations in the global chain system. In the first step of the two-step cluster analysis, in the process before clustering, three clusters were formed, each of which represents one degree of seasonality. The difference between the clusters is defined by the value of logarithmic functions with the largest credibility and not by the Euclidean measure because a qualitative variable is not present. For clustering criteria, the SchwarzBayesian information criteria were used. In the second step of the two-step cluster analysis of the obtained clusters, a hierarchical method has been applied, and each hotel has been divide into individual cluster, correspondingly to seasonality.

Taking into account that the distribution of performance indicators (room occupancy, ADR and RevPAR) is not normally distributed, a Kruskal-Wallis test was used to test the difference between arithmetic means of these three populations. Due to the disturbed assumption on the normality of variables distribution of a number of days in high season, testing was made by the Mann-Whitney test on the differences of the average number of days in high season for GCHs with dependence on the type of hotels. Followed is used the Chi-square test to examine the dependence of the degree of seasonality on the type of hotels. Analysis was conducted with the SPSS statistical software (Statistical Package for the Social Sciences).

\section{DATA ANALYSIS AND RESULTS}

First hypotheses presume that business performance is higher in GCHs with the lower seasonality. In order to examine this hypothesis, performance indicators have been chosen and observed with consideration of their relation to the degree of seasonality. The business performance of GCHs in selected countries is approximated by following indicators for 2014: room occupancy, ADR and RevPAR.

Hotels have been divide into individual cluster, correspondingly to seasonality. Each cluster represents one of the stages of seasonality, while at the center of each cluster, or their centroid values, they formed boundaries of every degree of seasonality. The boundary between the two adjacent clusters, or a certain degree of seasonality, is defined as half of the sum of the centrodine values of adjacent clusters. Based on this, three degrees of seasonality were determined, while using the hierarchical method determined the degree of seasonality of each hotel in the sample (Table 1). 
ToSEE - Tourism in Southern and Eastern Europe, Vol. 5, pp. 757-772, 2019

S. Vrkljan, P. Barišić, K. Vrenc: ANALYSIS OF SEASONALITY IMPACT ON THE BUSINESS ...

Table 1: The share of hotels in global chain in clusters according to seasonality

\begin{tabular}{|l|c|c|c|c|}
\hline \multicolumn{1}{|c|}{$\begin{array}{c}\text { Seasonality } \\
\text { degree }\end{array}$} & $\begin{array}{c}\text { Centrodine } \\
\text { values of clusters }\end{array}$ & $\begin{array}{c}\text { Season in } \\
\text { days }\end{array}$ & $\begin{array}{c}\text { Number of } \\
\text { the hotels }\end{array}$ & Size \\
\hline High degree & 99,85 & do 158 dana & 85 & $43,4 \%$ \\
\hline Medium degree & 215,34 & $159-284$ dana & 70 & $35,7 \%$ \\
\hline Low degree & 352,73 & od 285 dana & 41 & $20,9 \%$ \\
\hline
\end{tabular}

Source: Analysis of authors

From the total sample of $196 \mathrm{GCHs}, 85$ of them, or $43.4 \%$ hotels operate with a high degree of seasonality. By applying the two-step cluster analysis, it was noted that high degree of business performance characterize those hotels with the high season lasting for 158 days a year. On the other hand, $35.7 \%$ of hotels operate with a medium degree of seasonality and for them, the high season lasts between 159 and 284 days. 20,9\% of researched hotels have a low degree of seasonality and for these hotels, the high season lasts 285 days or more.

After defining the degree of seasonality, the hypothesis was tested. Table 2 shows the average data on performance indicators depending on the degree of seasonality according to the number of days. It can be noted that the arithmetic mean of all the performance indicators is decreased in the case of a high degree of seasonality, while the performance is the highest among those $\mathrm{HCHs}$ that operate with a lower degree of seasonality.

Table 2: Descriptive analysis of the degree of seasonality according to the number of days with regard to the selected performance indicators

\begin{tabular}{|c|c|c|c|c|c|c|}
\hline & & $\begin{array}{c}\text { Sample } \\
\text { size }\end{array}$ & $\begin{array}{c}\text { Arithmetic } \\
\text { mean }\end{array}$ & $\begin{array}{l}\text { Standard } \\
\text { deviation }\end{array}$ & $\begin{array}{c}\text { Minimal } \\
\text { value }\end{array}$ & $\begin{array}{c}\text { Maximum } \\
\text { value }\end{array}$ \\
\hline \multirow{4}{*}{$\begin{array}{l}\text { Room } \\
\text { occupancy }\end{array}$} & High & 85 & 134,44 & 90,15 & 13 & 365 \\
\hline & Medium & 70 & 200,90 & 87,75 & 0 & 365 \\
\hline & Low & 41 & 206,54 & 94,48 & 40 & 336 \\
\hline & Total & 196 & 173,26 & 96,03 & 0 & 365 \\
\hline \multirow{4}{*}{ ADR } & High & 85 & 171,41 & 133,36 & 49 & 998 \\
\hline & Medium & 70 & 208,96 & 123,61 & 70 & 490 \\
\hline & Low & 41 & 210,56 & 108,09 & 60 & 580 \\
\hline & Total & 196 & 193,01 & 125,79 & 49 & 998 \\
\hline \multirow{4}{*}{ RevPAR } & High & 85 & 24956,09 & 29877,77 & 1430 & 186150 \\
\hline & Medium & 70 & 43731,91 & 33879,45 & 0 & 128250 \\
\hline & Low & 41 & 46665,51 & 36785,36 & 3290 & 179800 \\
\hline & Total & 196 & 36203,00 & 34157,93 & 0 & 186150 \\
\hline
\end{tabular}

Source: Analysis of authors 
ToSEE - Tourism in Southern and Eastern Europe, Vol. 5, pp. 757-772, 2019

S. Vrkljan, P. Barišić, K. Vrenc: ANALYSIS OF SEASONALITY IMPACT ON THE BUSINESS ...

As the distribution of performance indicators is not normally distributed, a KruskalWallis test was used to test the difference between arithmetic means of these three populations. The null hypothesis of Kruskal-Wallis test assumes that there is no difference in the business performance of GCHs with dependence on the degree of seasonality (Table 3).

\section{Table 3: Results of Kruskal-Wallis test}

\begin{tabular}{|c|c|c|c|c|}
\hline \multicolumn{5}{|l|}{ Ranks } \\
\hline & & TwoStep Cluster Nun & $\mathrm{N}$ & Mean Rank \\
\hline \multirow{4}{*}{\multicolumn{2}{|c|}{ Room occupancy }} & High & 85 & 75,61 \\
\hline & & Medium & 70 & 114,76 \\
\hline & & Low & 41 & 118,20 \\
\hline & & Total & 196 & \\
\hline \multirow{4}{*}{\multicolumn{2}{|c|}{ ADR }} & High & 85 & 84,39 \\
\hline & & Medium & 70 & 107,21 \\
\hline & & Low & 41 & 112,89 \\
\hline & & Total & 196 & \\
\hline \multirow{4}{*}{\multicolumn{2}{|c|}{ RevPAR }} & High & 85 & 74,62 \\
\hline & & Medium & 70 & 115,66 \\
\hline & & Low & 41 & 118,71 \\
\hline & & Total & 196 & \\
\hline \multicolumn{4}{|c|}{ Test Statistics, $^{\text {b }}$} & \\
\hline & $\begin{array}{c}\text { Room } \\
\text { occupancy }\end{array}$ & Average room rate & RevPAR & \\
\hline Chi-Square & 24,555 & 9,554 & 26,680 & \\
\hline Df & 2 & 2 & 2 & \\
\hline Asymp. Sig. &, 000 &, 008 &, 000 & \\
\hline \multicolumn{4}{|c|}{ a. Kruskal-Wallis Test } & \\
\hline \multicolumn{4}{|c|}{ b. Grouping Variable: TwoStep Cluster Number } & \\
\hline
\end{tabular}

Source: Analysis of authors

P-value in the case of availability of rooms and RevPAR is approximately 0,000 , while the p-value in the case of ADR is equal to 0,008. Therefore, for all three indicators can be established that there is a difference in the business performance of GCHs with dependence on the degree of seasonality, which is why the hypothesis H1 is confirmed. GCHs business performance is higher in hotels with lower seasonality.

The second hypothesis presumes that the degree of seasonality of GCHs is lower for business hotels than leisure hotels. The degree of seasonality was determined in the previous hypothesis. Business and leisure hotels were determined based on answers to questions on the share of business or leisure guests of the total number of guests in a particular hotel. If the share of business guests is higher than the share of leisure guests in the total number of guests, the hotel is considered as a business hotel. If the share of leisure guests is greater than the share of business guests in the total number of guests, then the hotel is considered as a leisure hotel. By using this criteria in the observed sample were identified 84 business hotels (42.9\%) and 112 leisure hotels $(57.1 \%)$, as shown in Table 4 . From the same table it is noticeable that the average number of days of high season is higher in business hotels than in leisure hotels. 
ToSEE - Tourism in Southern and Eastern Europe, Vol. 5, pp. 757-772, 2019

S. Vrkljan, P. Barišić, K. Vrenc: ANALYSIS OF SEASONALITY IMPACT ON THE BUSINESS ...

Table 4: Descriptive analysis of the number of high season days with regard to classification of hotels on business and leisure hotels

\begin{tabular}{|l|c|c|c|c|c|c|}
\hline \multicolumn{1}{|c|}{ Number of high season days } & $\begin{array}{c}\text { Structure } \\
(\%)\end{array}$ & $\mathrm{N}$ & $\begin{array}{c}\text { Arithmetic } \\
\text { mean }\end{array}$ & $\begin{array}{c}\text { Standard } \\
\text { deviation }\end{array}$ & Minimum & Maximum \\
\hline Business hotel & 42,9 & 84 & 209,38 & 105,962 & 30 & 365 \\
\hline Leisure hotel & 57,1 & 112 & 182,46 & 96,561 & 30 & 365 \\
\hline Total & $100 \%$ & 196 & 193,99 & 101,316 & 30 & 365 \\
\hline
\end{tabular}

Source: Analysis of authors

Descriptive analysis indicates that the seasonality is somewhat lower for business hotels in relation to the leisure hotels. For the purpose of robustness of analysis, the hypothesis has been tested in two ways. Due to the disturbed assumption on the normality of variables distribution of a number of days in high season, testing was made by the MannWhitney test on the differences of the average number of days in high season for GCHs with dependence on the type of hotels. Followed is used the Chi-square test to examine the dependence of the degree of seasonality on the type of hotels.

Table 5: Results of the Kolmogorov-Smirnov and Shapiro-Wilk test on the normality of distribution of number of days in high season

\begin{tabular}{|c|c|c|c|c|c|c|}
\hline \multicolumn{7}{|l|}{ Tests of Normality } \\
\hline & \multicolumn{3}{|c|}{ Kolmogorov-Smirnov ${ }^{a}$} & \multicolumn{3}{|c|}{ Shapiro-Wilk } \\
\hline & Statistic & Df & Sig. & Statistic & Df & Sig. \\
\hline $\begin{array}{l}\text { Number of days in high } \\
\text { season }\end{array}$ & ,123 & 196 & , 000 & 917 & 196 &, 000 \\
\hline
\end{tabular}

Source: Analysis of authors

P-value depending on the type of hotel is 0.089 and p-value is less than the theoretical significance level of 5\%, thereby the null hypothesis cannot be dismissed. In other words, the average number of the high season depending on the type of hotel do not differ significantly.

Table 6: Results of the Mann-Whitney test on the number of days in high season

\begin{tabular}{|c|c|c|c|c|}
\hline \multicolumn{5}{|l|}{ Ranks } \\
\hline & Type of hotel & $\mathrm{N}$ & Mean Rank & $\begin{array}{l}\text { Sum of } \\
\text { Ranks }\end{array}$ \\
\hline \multirow{3}{*}{ Number of days in high season } & Business hotel & 84 & 106,43 & 8940,00 \\
\hline & Leisure hotel & 112 & 92,55 & 10366,00 \\
\hline & Total & 196 & & \\
\hline
\end{tabular}

\begin{tabular}{|l|r|}
\hline Test Statistics \\
\hline \multicolumn{2}{|c|}{ Number of days in high season } \\
\hline Mann-Whitney U & 4038,000 \\
\hline Wilcoxon W & 10366,000 \\
\hline Z & $-1,699$ \\
\hline Asymp. Sig. (2-tailed) &, 089 \\
\hline a. Grouping Variable: Type of hotel \\
\hline
\end{tabular}

Source: Analysis of authors 
ToSEE - Tourism in Southern and Eastern Europe, Vol. 5, pp. 757-772, 2019

S. Vrkljan, P. Barišić, K. Vrenc: ANALYSIS OF SEASONALITY IMPACT ON THE BUSINESS ...

To confirm the results obtained by using the Mann-Whitney test, the Chi-square test of independence was conducted, which analyses if the degree of seasonality depends on the type of GCHs. The assumption is that the degree of seasonality is lower for business hotels in relation to leisure hotels.

Table 7: Results of the Chi-square test of independence of the degree of seasonality with regard to hotel types

\begin{tabular}{|c|c|c|c|c|c|c|c|c|}
\hline \multicolumn{9}{|c|}{ Hotel type * Degree of seasonality Cross tabulation } \\
\hline 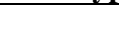 & +2 & (n) & & 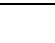 & Deg & ee of seaso & ality & Total \\
\hline & & & & & High & Medium & Low & \\
\hline \multirow{4}{*}{$\begin{array}{l}\text { Type of } \\
\text { hotel }\end{array}$} & \multirow{2}{*}{\multicolumn{2}{|c|}{ Business hotel }} & \multicolumn{2}{|c|}{ Count } & 34 & 28 & 22 & 84 \\
\hline & & & \multicolumn{2}{|c|}{$\begin{array}{l}\% \text { within Type of } \\
\text { hotel }\end{array}$} & $40,5 \%$ & $33,3 \%$ & $26,2 \%$ & $100,0 \%$ \\
\hline & \multirow{2}{*}{\multicolumn{2}{|c|}{ Leisure hotel }} & \multicolumn{2}{|c|}{ Count } & 51 & 42 & 19 & 112 \\
\hline & & & \multicolumn{2}{|c|}{$\begin{array}{l}\% \text { within Type of } \\
\text { hotel }\end{array}$} & $45,5 \%$ & $37,5 \%$ & $17,0 \%$ & $100,0 \%$ \\
\hline \multirow{2}{*}{\multicolumn{2}{|c|}{ Total }} & \multicolumn{3}{|c|}{ Count } & 85 & 70 & 41 & 196 \\
\hline & & \multicolumn{3}{|c|}{$\begin{array}{l}\% \text { within Type of } \\
\text { hotel }\end{array}$} & $43,4 \%$ & $35,7 \%$ & $20,9 \%$ & $100,0 \%$ \\
\hline \multicolumn{6}{|c|}{ Chi-Square Tests } & & & \\
\hline & & Value & Df & \multicolumn{2}{|c|}{$\begin{array}{l}\text { Asymp. Sig. } \\
\text { (2-sided) }\end{array}$} & & & \\
\hline \multicolumn{2}{|c|}{ Pearson Chi-Square } & $2,470^{\mathrm{a}}$ & 2 & & ,291 & & & \\
\hline \multicolumn{2}{|c|}{ Likelihood Ratio } & 2,448 & 2 & & ,294 & & & \\
\hline \multicolumn{2}{|c|}{$\begin{array}{l}\text { Linear-by-Linear } \\
\text { Association }\end{array}$} & 1,645 & 1 & & ,200 & & & \\
\hline \multicolumn{2}{|c|}{$\mathrm{N}$ of Valid Cases } & 196 & & & & & & \\
\hline \multicolumn{6}{|c|}{$\begin{array}{l}\text { a. } 0 \text { cells }(0,0 \%) \text { have expected count less than } 5 \text {. The } \\
\text { minimum expected count is } 17,57 \text {. }\end{array}$} & & & \\
\hline
\end{tabular}

It can be concluded that the basic preconditions for the application of the Chi-square test are met since the minimum value of the expected frequency is 17,57 and none of the expected frequencies are less than 5. Looking at the table of contingency it may be noted that, depending on the hotel type, there is no significant difference in the degree of seasonality. Between both business and leisure hotels, most of the hotels do business with a high degree of seasonality. In the total sample, $40.5 \%$ of business hotels operate with a high degree of seasonality, while $26.2 \%$ of business hotels operate with a low degree of seasonality. On the other hand, $45.5 \%$ of leisure hotels have the high degree of seasonality, or $17.0 \%$ of leisure hotels have a low degree of seasonality. Although the descriptive statistics point to a different conclusion, as per further testing and finally observing the p-value of the Chi-square test, which is 0.291 , it can be concluded that the degree of seasonality is not dependent on the hotel type. Business hotels do not operate with a lower degree of seasonality in relation to leisure hotels. Hypothesis $\mathrm{H} 2$ that assumed that the degree of seasonality of the GCHs is lower for business hotels than leisure hotels cannot be accepted. We conclude that hotels consider seasonality as an external factor that they cannot influence on, and which is the same for all hotels in the same spatial and climatic environment. 
ToSEE - Tourism in Southern and Eastern Europe, Vol. 5, pp. 757-772, 2019

S. Vrkljan, P. Barišić, K. Vrenc: ANALYSIS OF SEASONALITY IMPACT ON THE BUSINESS ...

\section{CONCLUSION}

Seasonality is an external factor that affects the business performance of hotels. We are now seeing the emergence of new trends in tourism demand, which constitute a departure from the classical holiday, seasonal tourism. Therefore, following these trends, the tourism offer can be adjusted to minimize or neutralize the seasonality as characteristic of the tourism offer. The reduction of seasonality can additionally, and should, influence state and local governments through the development of additional tourism products that would allow an extension of the season and possibly influence through public-private and private-private partnerships as well. This way it can enable hotels to achieve better business results and a better life standard for local communities.

One of the main objectives of this paper was to test whether there is a correlation between the degree of seasonality and business performance of GCHs with emphasis on business and leisure hotels. The business performance of hotels in Croatia, Italy, Spain and Turkey is approximated by indicators gathered by a survey and by using the data on the (i) availability of rooms in 2014, (ii) the average daily room rate in 2014 and (iii) revenue per available room in 2014. All selected countries are on the European Mediterranean and are influenced by seasonality due to climate conditions.

By nonparametric Kruskal-Wallis test was found among all three selected indicators of business performance that there is a difference in the performance of GCHs depending on the degree of seasonality. The lower is the degree of seasonality, the business performance of GCHs is higher.

Further, it was researched whether the degree of seasonality is lower for business or leisure hotels. Tests of normality distribution for a number of days in high season were carried out using the Kolmogorov-Smirnov and Shapiro-Wilk test. Although the results of the descriptive statistics have indicated a different conclusion, the testing of MannWhitney mean differences test and chi-square test of dependence degree of seasonality on the hotel type it was concluded that the degree of seasonality is not dependent on the hotel type. Business hotels do not have a lower degree of seasonality in relation to leisure hotels. By orientation on a single type of a hotel, leisure or business, it is impossible to effect a more favorable degree of seasonality.

The research shows that the seasonality of hotel business in the global chain system in Mediterranean destinations is not lower in business hotels compared to leisure hotels and vice versa. Therefore, it is not necessary to strive for an exclusive or predominant orientation on one of these two types of hotels, but choose the optimal combination of specialized offer that will affect on business performance, since none of the types can affect a more favorable degree of seasonality. These findings are in contrast to Lam and Lei (2010) findings focusing on hotels in a gambling destination, according to which the focus on a particular segment of guests may positively affect the seasonality of business.

The limitations of research were the small number of GCHs in Croatia and lower response rates of hotels in Turkey. The support to the research through telephone contacts with sales directors was needed to ensure a higher respond to the questionnaire sent as a form and as a link by e-mails. 
ToSEE - Tourism in Southern and Eastern Europe, Vol. 5, pp. 757-772, 2019

S. Vrkljan, P. Barišić, K. Vrenc: ANALYSIS OF SEASONALITY IMPACT ON THE BUSINESS ...

In future research recommendations is detailed analysis of the nature of the link performance indicators GCHs with a number of operating days in the calendar year, and determine whether there is a difference in the business performance. In addition, comparing the results for GCHs with results for independent hotels would be advisable. Further research in this field is necessary for more successful business and adjustment of destination management.

\section{REFERENCES}

Angelo, R.M. and Vladimir, A.N. (2004), Hospitality Today - An Introduction, 5th ed., Michigan: Educational Institute, American Hotel \& Lodging Association.

Avelini Holjevac, I. (1998), Kontroling - Upravljanje poslovnim rezultatom, Opatija: Faculty of Tourism and Hospitality Management.

Bartoluci, M. (2013), Upravljanje razvojem turizma i poduzetništva - Turistička politika, razvoj i poduzetništvo u turizmu, Zagreb: Školska knjiga

Bartoluci, M. and Škorić, S. (2009), Menadžment sportskog i nautičkog turizma, Karlovac: Veleučilište u Karloveu.

Baum, T, Hagen, L. (1999), "Responses to seasonality: the experiences of peripheral destinations", International Journal of Tourism Research, Vol. 1, No. 5, pp. 299-312, https://doi.org/10.1002/(SICI)1522-1970(199909/10)1:5<299::AID-JTR198>3.0.CO;2-L.

BarOn RV (1975), Seasonality in Tourism - a Guide to the Analysis of Seasonality and Trends for Policy Making, Technical Series, No. 2, The Economist Intelligence Unit Ltd: London.

Best Western International, available on: http://www.bestwestern.com/.

Butler, R.W. (1994), "Seasonality in tourism: issues and problems", In Tourism: the State of the Art, Seaton, A.V. (ed.), Wiley: Chichester, pp. 332-339.

Butler, R.W. and Mao, B. (1997), "Seasonality in tourism: problems and measurement", In Quality Management in Urban Tourism, Murphy, P. (ed.), Wiley: Chichester, pp. 9-23.

Carmona Olmos, G.H. (2012), "Hospitality Competitiveness Measurement System", Journal of Global Business and Technology, Vol. 8, No. 2, pp. 29-37.

Cerović, Z., Pavia, N. and Galičić, V. (2005), Organizacija i kategorizacija ugostiteljskih objekata, Opatija: Faculty of Tourism and Hospitality Management.

Cross, R. (1997), "Launching the Revenue Rocket Can Work for Your Business - How Revenue Management", Cornell Hotel and Restaurant Administration Quarterly, Vol. 35, No. 2, pp. 2-13, https://doi.org/10.1016/S0010-8804(97)81474-7.

Čavlek, N., et al. (2011), Turizam - ekonomske osnove i organizacijski sustav, Zagreb: Školska knjiga.

Dulčić, A. and Petrić, L. (2001), Upravljanje razvojem turizma, Zagreb: Mate.

Duro, J.A. (2016), "Seasonality of hotel demand in the main Spanish provinces: Measurements and decomposition exercises", Tourism Management, Vol. 52, pp. 52-63, https://doi.org/10.1016/j.tourman.2015.06.013

Espinet, J. M., Fluvià, M. and Saló, A. (2012), "Hotel characteristics and seasonality in prices: an analysis using Spanish tour operators' brochures”, Tourism Economics, Vol. 18, No. 4, pp. 749-767, https://doi.org/10.5367/te.2012.0145.

Frechtling, D. C. (2001), Forecasting Tourism Demand: Methods and Strategies, Butterworth-Heinemann: Oxford

Galičić, V., Ivanović, S. and Lupić, M. (2005), Hotelska prodaja i recepcijsko poslovanje, Opatija: Faculty of Tourism and Hospitality Management.

Gazzoli, G., Kim, W.G. and Palakurthi, R. (2008), "Online distribution strategies and competition: are the global hotel companies getting it right?", International Journal of Contemporary Hospitality Management, Vol. 20, No. 4, pp. 375-387 https://doi.org/10.1108/09596110810873499.

Gračan, D. and Rudančić Lugarić, A. (2011), "Business Tourism - Modern Form for Improvement of the Competitiveness of Croatian Tourism”, Ekonomska misao i praksa dbk., year XX, No. 2, pp. 579 590.

Grant, M., Human, B. and Le Pelley, B. (1997), "Seasonality", In Insights-Tourism Intelligence Papers, British Tourist Authority, English Tourist Board, London, p. 9

Hartmann, R. (1986), “Tourism, seasonality and social change”, Leisure Studies, Vol. 5, No. 1, pp. 25-33, https://doi.org/10.1080/02614368600390021.

Hilton Worldwide, available on: http://www.hiltonworldwide.com/ 
ToSEE - Tourism in Southern and Eastern Europe, Vol. 5, pp. 757-772, 2019

S. Vrkljan, P. Barišić, K. Vrenc: ANALYSIS OF SEASONALITY IMPACT ON THE BUSINESS ...

Kempinski, available on: http://www.kempinski.com/

Koenig-Lewis, N. and Bischoff, E.E. (2005), "Seasonality Research: The State of the Art", International Journal of Tourism Research, Vol. 7, pp. 201-219, https://doi.org/ 10.1002/jtr.531.

Kožić, I. (2013), "Kolika je sezonalnost turizma u Hrvatskoj”, Ekonomski vjesnik, Vol. 26, No. 22, pp. 470480.

Lam, C. and Lei, C. (2010), "Hotel occupancy rate in a gambling destination: A longitudinal study of the Macao hotel industry 2004-2007”, Journal of Hospitality and Tourism Management, Vol. 17, No. 1, pp. 34-43, https://doi.org/10.1375/jhtm.17.1.34.

Lumsdon, L. (1997), Tourism Marketing, London: International Thomson Business Press.

Marriott Hotels, available on: http://www.marriott.com/.

Meliá Hotels International, available on: http://www.melia.com/.

O'Neill, J.W. and Mattila, A.S. (2006), "Strategic Hotel Development and Positioning, The Effects of Revenue Drivers on Profitability", Cornell Hotel and Restaurant Administration Quarterly, Vol. 46, No. 2, pp. 146-154, https://doi.org/10.1177/0010880405281519.

Pereira, L.N. (2016), "An introduction to helpful forecasting methods for hotel revenue management", International Journal of Hospitality Management, Vol. 58, pp. 13-23, https://doi.org/10.1016/j.ijhm.2016.07.003.

Riera Font, A., Ripoll Penalva, A.M., and Juaneda Sampol, C.N. (2011), "Efficiency and Seasonality in the Balearic Hospitality Industry", Estudios de Economia Aplicada, Vol. 29, No. 3, pp. 845-862.

Ružić, D. (1997), Upravljanje marketingom u ugostiteljstvu, Osijek: Faculty of Economics in Osijek.

Sainaghi, R. (2011), "Price determinants of individual hotel: evidence from Milan", Tourism review, Vol. 66, No. 4, pp. 18-29, https://doi.org/10.1108/16605371111188713.

Sainaghi, R. and Canali, S. (2011), "Exploring the effects of destination's positioning on hotels' performance: the Milan case", Tourismos: An International Multidisciplinary Journal of Tourism, Vol. 6, No. 2, pp. 121-138.

Saló, A., Garriga, A., Vila, M. and Sayeras, J.M. (2012), "Differences in seasonal price patterns among second home rentals and hotels: empirical evidence and practical implications", Tourism Economics, Vol. 18, No. 4, pp. 731-747, https://doi.org/10.5367/te.2012.0141

Starwood Hotels \& Resorts Worldwide, Inc., available on: http://www.starwood hotels.com/.

Škorić, S. (2010), Kriteriji održivog razvoja u funkciji planiranja razvoja zimskog sportskog turizma, doctoral thesis, Zagreb: Ekonomski fakultet - Zagreb.

The Leading Hotels of the World, available on: http://www.lhw.com/.

The Rezidor Hotel Group, available on: http://www.rezidor.com/.

UNWTO (2018), Tourism Highlights, 2018 Edition, available on: https://www.e-unwto.org/doi/pdf/10.18111/9789284419876.

Vidić, K. (2002), “Gosti s visokom potrošnjom", Cro turizam, 8(2), pp. 28.

Vrkljan, S. (2016), Utjecaj čimbenika konkurentnosti na uspješnost poslovanja hotela u sustavu globalnih lanaca, doctoral thesis, Zagreb: Faculty of Economics \& Business Zagreb.

Walker, J.R. (2008), Introduction to Hospitality, $5^{\text {th }}$ edition, Pearson Prentice Hall.

Weatherford, L. (2016), "The history of forecasting models in revenue management", Journal of Revenue and Pricing Management, Vol. 15, No. 3-4, pp. 212-221, https://doi.org/10.1057/rpm.2016.18.

World Economic Forum (2015), The Travel \& Tourism Competitiveness Report 2015 - Growth through Shock, available on: http://www3.weforum.org/docs/TT15/WEF_Global_Travel\&Tourism_Report_2015.pdf.

Xiao, Q., O'Neill, J.W. and Mattila, A.S. (2012), "The role of hotel owners: the influence of corporate strategies on hotel performance", International Journal of Contemporary Hospitality Management, Vol. 24, No. 1, pp. 122-139, https://doi.org/10.1108/09596111211197836. 
ToSEE - Tourism in Southern and Eastern Europe, Vol. 5, pp. 757-772, 2019

S. Vrkljan, P. Barišić, K. Vrenc: ANALYSIS OF SEASONALITY IMPACT ON THE BUSINESS ...

Sanela Vrkljan, PhD, Lecturer

Aspira University College

Heinzelova ulica 62, Zagreb, Croatia

Phone: +385-99-7830202

E-mail: sanela.vrkljan@gmail.com

Petra Barišić, $\mathrm{PhD}$, Postdoctoral researcher

University of Zagreb, Faculty of Economics and Business

Department of Tourism

Trg J. F. Kennedya 6, Zagreb, Croatia

Phone: +385-1-2383151

E-mail: petra.barisic@ net.efzg.hr

Katarina Vrenc, Student of Gastronomy

Aspira University College

Heinzelova ulica 62, Zagreb, Croatia

Phone: +385-95-3810708

E-mail: katarinavrenc@gmail.com 